\title{
PENGARUH KEPADATAN Nannochloropsis sp. PADA PEMELIHARAAN LARVA KERAPU BEBEK (Cromileptes altivelis) SECARA TERKONTROL
}

\author{
Suko Ismi, Yasmina Nirmala Asih, Bejo Slamet, dan Ketut Suwirya \\ Balai Besar Penelitian dan Pengembangan Budidaya Laut \\ JI. Br. Gondol, Kec. Gerokgak, Kab. Buleleng, Kotak Pos 140, Singaraja, Bali 81101 \\ E-mail: sukoismi@yahoo.com
}

(Naskah diterima: 16 Februari 2012; Disetujui publikasi: 14 Agustus 2012)

\begin{abstract}
ABSTRAK
Pembenihan kerapu bebek (Cromileptes altivelis) sudah berhasil dikembangkan di tingkat petani secara massal, namun terdapat beberapa kendala. Salah satu kendala pada saat pemeliharaan larva adalah seringnya terjadi kematian setelah penambahan plankton Nannochloropsis sp. Kematian tersebut disebabkan pemberian plankton yang tidak tepat baik kualitas maupun kuantitasnya sehingga menyebabkan turunnya kualitas air pada tangki pemeliharaan larva. Penelitian ini bertujuan untuk mengetahui penambahan optimal Nannochloropsis sp. sehingga diperoleh jumlah kepadatan Nannochloropsis sp. yang tepat sebagai green water dan persediaan pakan rotifer pada bak pemeliharaan larva. Perlakuan yang dicoba adalah penambahan Nannochloropsis sp. dengan kepadatan yang berbeda yaitu: A. Tanpa Nannochloropsis sp.; B. $100.000 \mathrm{sel} / \mathrm{mL}$; C. $300.000 \mathrm{sel} / \mathrm{mL}$; dan D. $500.000 \mathrm{sel} / \mathrm{mL}$. Hasil yang diperoleh pada perlakuan D (penambahan Nannochloropsis sp. $500.000 \mathrm{sel} / \mathrm{mL}$ ) menghasilkan sintasan 26,8\%; lebih tinggi dari perlakuan yang lain, berikut perlakuan C, B, dan A masing-masing 19,5\%; 14,2\%; dan 3,5\% sedangkan panjang total larva umur 45 hari relatif sama antara $2,47-2,53 \mathrm{~cm}$.
\end{abstract}

KATA KUNCl: kepadatan, Nannochloropsis sp., larva, kerapu bebek

ABSTRACT: Optimum density of Nannochloropsis sp. in larval rearing of humpback grouper (Cromileptes altivelis). By: Suko Ismi, Yasmina Nirmala Asih, Bejo Slamet, and Ketut Suwirya

Humpback grouper hatchery has been successfully developed at small-scale farms. However, one of the constraints in larval rearing is frequent mortality after addition of plankton Nannochloropsis sp. The mortality larval was due to improper addition (quality and quantity) of phytoplankton causing declines in water quality in larval rearing tank. This study attempted to determine the optimal addition of Nannochloropsis sp. as the green water and feed for rotifers. The treatments were the addition of Nannochloropsis sp. in various densities: A. Without Nannochloropsis sp.; B. 100,000 cells $/ \mathrm{mL} ;$ C. 300,000 cells $/ \mathrm{mL}$; and D. 500,000 cells $/ \mathrm{mL}$. Results obtained in treatment $D$ (addition of Nannochloropsis sp. 500,000 cells $/ \mathrm{mL}$ ) had higher survival rate than that of other treatments (26.80\%), followed by treatment $C$ (19.50\%), treatment $B(14.20 \%)$, and treatment $A$ (3.50\%). Measurement of the total length on day 45 as growth indicator showed that the growths were similar in all treatments $(2.47$ to $2.53 \mathrm{~cm})$.

KEYWORDS: density, Nannochloropsis sp., larvae, humpback grouper 


\section{PENDAHULUAN}

Ikan kerapu merupakan jenis ikan laut bernilai ekonomi penting, mempunyai pangsa pasar luas dan harganya pun relatif tinggi, khususnya bila dijual dalam keadaan hidup di luar negeri seperti Singapura, Hongkong, Taiwan, dan Cina Selatan (Chou \& Lee, 1998).

Ikan kerapu hidup yang diperdagangkan saat ini sebagian besar berasal dari penangkapan di alam. Budidaya kerapu saat ini mulai berkembang terutama kerapu macan (Epinephelus fuscoguttatus) dan kerapu bebek (Cromileptes altivelis). Untuk mencukupi kebutuhan benih kerapu keperluan budidaya, maka perlu dikembangkan pembenihan secara buatan, mengantisipasi kebutuhan benih secara berkesinambungan (Sugama et al., 2001; Sutarmat et al., 2002; 2003).

Pembenihan kerapu telah dirintis sejak tahun 1994. Teknologi pembenihan kerapu telah diadopsi oleh masyarakat khususnya Hatcheri Skala Rumah Tangga (HSRT) di sekitar Gondol sejak tahun 1999. Sejak saat itu, HSRT tidak saja memproduksi benih bandeng namun juga telah dapat memproduksi benih kerapu (Kawahara \& Ismi, 2003).

Kendala pada saat pemeliharaan larva adalah seringnya terjadi kematian setelah penambahan plankton Nannochloropsis sp. yang berfungsi sebagai green water atau peneduh selain juga berfungsi untuk pakan sisa rotifer pada bak larva (Ismi, 2005). Kematian tersebut disebabkan oleh pemberian plankton yang tidak tepat baik kualitas maupun kuantitasnya, sehingga menyebabkan turunnya kualitas air pada tangki pemeliharaan sehingga larva mengalami stres dan kematian. Penelitian ini bertujuan untuk mengetahui pengaruh kepadatan optimal pemberian Nannochloropsis sp. pada pemeliharaan larva kerapu bebek (Cromileptes altivelis). Terhadap produksi benih dan evaluasi kelayakan usaha.

\section{BAHAN DAN METODE}

Ikan kerapu yang dipakai dalam percobaan ini adalah kerapu bebek, tangki pemeliharaan ukuran 3-4 $\mathrm{m}^{3}$, telur kerapu bebek ditebar dengan kepadatan 10 butir/L, pemeliharaan hingga yuwana (45 hari). Penelitian diulang 3 kali dengan ulangan waktu, dan data yang diperoleh dianalisis secara deskriptif.

Manajemen pembenihan mengikuti aturan cara pembenihan ikan yang baik (Anonim,
2008). Larva pertama kali diberi makan setelah buka mulut yaitu pada hari ke-3 dan pakan yang diberikan adalah pakan alami rotifer dengan kepadatan awal 5 ind./mL. Rotifer biasanya diberikan dua kali sehari pagi dan sore tergantung jumlah sisa di dalam tangki pemeliharaan. Rotifer dalam air pemeliharaan larva dikontrol setiap hari dan jika rotifer berkurang dari jumlah tersebut, maka ditambahkan hingga mencukupi. Setelah umur larva 8 hari hingga umur 25 hari, pemberian rotifer ditingkatkan menjadi 10-15 ind./mL. Saat larva hari ke-2 sampai hari ke-25, pada tangki pemeliharaan ditambahkan Nannochloropsis sp. sebagai green water di samping sebagai pakan rotifer.

Pada umur larva 8 hari mulai diberi pakan buatan yang berupa mikro pelet dan ukuran pelet disesuaikan dengan ukuran mulut larva. Pelet diberikan 4 kali sehari dengan cara ditaburkan di atas permukaan air. Pada awal pemberian mikro pelet hanya sedikit, untuk melatih larva makan. Setelah larva aktif memakan pemberian mikro pelet dilakukan hingga kenyang/inlibitum, pemberian pakan dihentikan jika ikan sudah tidak mau makan lagi. Nauplii Artemia diberikan saat larva berumur 20 hari untuk larva kerapu bebek. Pemberian Artemia dilakukan hingga larva berumur 45 hari, banyaknya pemberian disesuaikan dengan perkiraan jumlah larva dan hanya diberikan 2 kali sehari pagi dan sore. Nauplii Artemia ini harus termakan habis oleh larva selama 1-2 jam setelah diberikan.

Pemberian minyak ikan sebanyak $0,1 \mathrm{~mL} /$ $\mathrm{m}^{2}$ luas permukaan air dilakukan dua kali sehari pagi dan sore, dengan cara diteteskan di atas permukaan air dekat dengan aerasi, berfungsi untuk menutup permukaan lapisan air untuk menghindari kematian larva sebelum umur 5 hari akibat terjerat lapisan permukaan air (Sugama et al., 2001; Ismi et al., 2004; 2007). Pola pemberian pakan dan manajemen air dan lain-lain dapat dilihat pada Tabel 1 dan 2 .

Pada penelitian ini perlakuannya adalah penambahan Nannochloropsis sp. dengan kepadatan yang berbeda yaitu: A. Tanpa Nannochloropsis sp.; B. Kepadatan Nannochloropsis sp. $100.000 \mathrm{sel} / \mathrm{mL}$; C. Kepadatan Nannochloropsis sp. $300.000 \mathrm{sel} / \mathrm{mL}$; dan D. Kepadatan Nannochloropsis sp. 500.000 $\mathrm{sel} / \mathrm{mL}$. Plankton yang dipakai adalah Nannochloropsis sp. konsentrat, cara pemberian mengacu pada rumus berikut: 
Tabel 1. Pola pemberian pakan pada pemeliharaan larva kerapu bebek (Cromileptes altivelis) selama percobaan

Table 1. Feeding management in larval rearing humpback grouper (Cromileptes altivelis) during experiment

\begin{tabular}{|c|c|c|c|c|c|c|c|c|c|c|c|}
\hline \multirow{2}{*}{$\begin{array}{l}\text { Pakan } \\
\text { Feeding }\end{array}$} & \multicolumn{11}{|c|}{ Hari setelah menet as (Days after hatching) } \\
\hline & 2 & 3 & 8 & 15 & 20 & 25 & 30 & 35 & 40 & 45 & 50 \\
\hline Nannochloropsis sp. & & & & & & & & & & & \\
\hline Rotifer & & $\cdots$ & 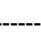 & 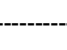 & & & & & & & \\
\hline Nauplii Artemia & & & & & & & & & & ----בי & \\
\hline Pakan buatan (Artificial feed) & & & & & & & & & & & \\
\hline
\end{tabular}

Table 2. Manajemen air, pembersihan dasar tangki, dan pemberian minyak ikan pada pemeliharaan larva kerapu bebek (Cromileptes altivelis)

Table 2. Water management, bottom tanks cleaning, and adding fish oil during humpback grouper (Cromileptes altivelis) larval rearing

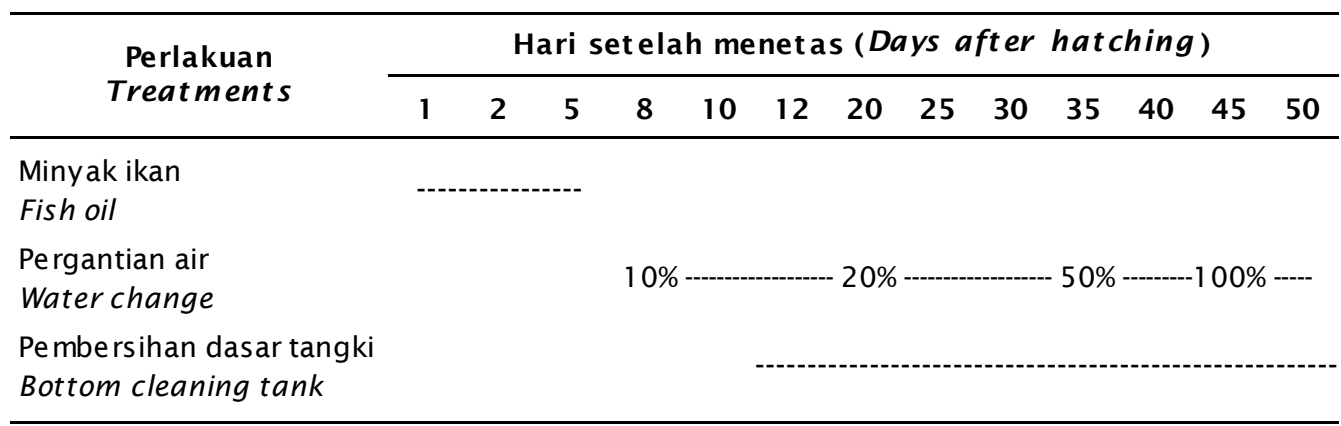

Volume Nannochloropsis sp.
konsentrat yang akan diberikan $=\frac{\mathrm{VxK}}{\mathrm{NK}}$

di mana:

$\mathrm{V}=$ Volume air pemeliharaan $(\mathrm{mL})$

$\mathrm{K}=$ Kepadatan Nannochloropsis sp. sesuai perlakuan (sel/mL)

NK $=$ Kepadatan Nannochloropsis sp. konsentrat $(\mathrm{sel} / \mathrm{mL})$

Parameter yang diamati adalah produksi benih dievaluasi dari sintasan, pertumbuhan, kepadatan Nannochloropsis sp., kepadatan rotifer dalam air pemeliharaan, rotifer dalam perut larva, abnormalitas, analisis ekonomi, dan kualitas air yang meliputi: DO, salinitas, suhu, $\mathrm{pH}$, amonia, nitrat, nitrit, dan fosfat.

\section{HASIL DAN BAHASAN}

Larva ikan kerapu bebek yang dipelihara dengan penambahan Nannochloropsis sp. kepadatan $500.000 \mathrm{sel} / \mathrm{mL}$ menghasilkan sintasan yang lebih tinggi yaitu $26,8 \%$ dengan jumlah benih 16.080 ekor dibandingkan dengan perlakuan yang lain (Tabel 3). Sintasan yang paling kecil adalah pada perlakuan tanpa pemberian Nannochloropsis sp. yaitu 3,5\% dengan jumlah benih 2.100 ekor. Abnormalitas pada benih masih terjadi pada semua perlakuan, yang tertinggi pada penambahan Nannochloropsis sp. 300.000 sel/mL mencapai $24,3 \%$ dari benih yang dihasilkan berarti dari hasil sintasan 19,5\% atau 11.700 ekor benih yang cacat adalah 2.843 ekor.

Hasil sintasan kerapu bebek dalam percobaan ini sejalan dengan penelitian yang dilakukan pada larva barfin flounder (Verasper moseri), tropical spiny lobster (Panulirus homarus), dan red sea bream (Pagrus major), yang menghasilkan sintasan lebih tinggi pada pemeliharaan larva dengan penambahan Nannochloropsis sp. daripada pemeliharaan tanpa penambahan Nannochloropsis sp. 
Tabel 3. Sintasan, panjang total, dan abnormalitas kerapu bebek (Cromileptes altivelis) umur 45 hari pada pemeliharaan dengan penambahan kepadatan Nannochloropsis sp. yang berbeda

Table 3. Survival rate, total length, and deformities of humpback grouper (Cromileptes altivelis) 45 days old on reared in various densities of Nannochloropsis sp.

\begin{tabular}{|c|c|c|c|c|}
\hline $\begin{array}{l}\text { Perlakuan } \\
\text { Treatments }\end{array}$ & $\begin{array}{l}\text { Daya tetas telur } \\
\text { Hatching rate }\end{array}$ & $\begin{array}{c}\text { Sintasan } \\
\text { Survival rate }\end{array}$ & $\begin{array}{c}\text { Panjang } \\
\text { total (Total } \\
\text { length) }(\mathrm{cm})\end{array}$ & $\begin{array}{l}\text { Abnormalitas } \\
\text { Abnormality }\end{array}$ \\
\hline Tanpa (Without) & $60 \%$ & $3.50 \%$ & \multirow{2}{*}{2.53} & $3.53 \%$ \\
\hline Nannochloropsis sp. & $(60.000$ ekor $(p c s))$ & $(2.100$ e kor $(p c s))$ & & $(111$ ekor $(p c s))$ \\
\hline $100.000 \mathrm{sel} / \mathrm{mL}$ & $60 \%$ & $14.20 \%$ & \multirow{2}{*}{2.47} & $16.16 \%$ \\
\hline 100,000 cells $/ \mathrm{mL}$ & $(60.000$ ekor $(p c s))$ & $(8.520$ e kor $(p c s))$ & & $(1.377$ e kor $(p c s))$ \\
\hline $300.000 \mathrm{sel} / \mathrm{mL}$ & $60 \%$ & $19.50 \%$ & \multirow{2}{*}{2.47} & $24.30 \%$ \\
\hline 300,000 cells $/ \mathrm{mL}$ & $(60.000$ ekor $(p c s))$ & $(11.700$ e kor $(p c s))$ & & $(2.843$ e kor $(p c s))$ \\
\hline $500.000 \mathrm{sel} / \mathrm{mL}$ & $60 \%$ & $26.80 \%$ & \multirow{2}{*}{2.47} & $16.43 \%$ \\
\hline 500,000 cells $/ \mathrm{mL}$ & $(60.000$ ekor $(p c s))$ & $(16.080$ ekor $(p c s))$ & & $(2.642$ e kor $(p c s))$ \\
\hline
\end{tabular}

(Takaaki et al., 2002; Radhakrishnan et al., 2009; Okauchi, 2004).

Dari pengamatan pada pemeliharaan tanpa penambahan Nannochloropsis sp., larva kerapu banyak yang mati di permukaan air dibandingkan dengan yang menggunakan Nannochloropsis sp. Adanya green water Nannochloropsis sp. maka air pemeliharaan menjadi redup dan intensitas cahaya di air rendah sehingga larva tidak banyak mati di permukaan. Menurut Eri et al. (2003), pada red spotted grouper (Ephinephelus akaara) kematian larva di permukaan air meningkat seiring dengan meningkatnya intensitas cahaya pada air pemeliharaan larva.

Hasil pengukuran pertumbuhan panjang total larva kerapu bebek yang diukur setiap 5 hari sekali dalam percobaan ini dapat dilihat pada Gambar 1. Panjang total larva pada keempat perlakuan hampir sama pada umur 45 hari berkisar 2,47-2,53 cm (Tabel 3).

Kepadatan rotifer sebagai pakan dalam air dipertahankan agar mempunyai kepadatan yang cukup selama pemeliharaan (Gambar 2). Kepadatan rotifer selalu dihitung pagi dan sore hari dan ditambahkan jika kepadatannya berkurang, keadaan demikian dipertahankan hingga larva berumur 25 hari. Namun pada pemeliharaan tanpa Nannochloropsis sp., kepadatan rotifer lebih rendah jika dibandingkan dengan perlakuan yang lain. Hal ini disebabkan persediaan makanan untuk rotifer yang terdapat dalam air pemeliharaan tidak tercukupi sehingga banyak rotifer yang mati dan rotifer juga nampak pucat tidak berisi makanan seperti terlihat pada Gambar 3.

Nannochloropsis sp. adalah salah satu pakan rotifer yang mempunyai kandungan EPA dan n-3HUFA yang cocok untuk pemeliharaan ikan laut (Sorgeloss et al., 1988; Ostrowski \& Divakaran, 1990; Webster \& Lovell, 1990; Koven et al., 1990). Pada pemeliharaan larva tanpa Nannochloropsis sp., rotifer tidak mempunyai pakan sehingga nilai nutrisinya menurun, dibandingkan dengan rotifer yang cukup pakan Nannochloropsis sp. (Okauchi, 2004).

Jumlah rotifer yang ada dalam perut larva hingga umur 15 hari pada keempat perlakuan mempunyai pola yang sama, larva mulai memangsa rotifer setelah buka mulut yaitu umur 3 hari, jumlah rotifer dalam perut 3-5 individu dan jumlah rotifer yang dimangsa semakin bertambah sesuai dengan bertambahnya umur seperti nampak pada (Gambar 4), pada umur 15 hari rotifer dalam perut hingga 41-62 individu.

Cacat pada benih kerapu bebek hasil dari pembenihan hingga saat ini masih belum dapat dihindari. Pada penelitian ini, cacat masih terjadi pada semua perlakuan yaitu berkisar antara 3,53\%-24,3\% (umur 45 hari). Beberapa macam cacat yang dialami juvenil antara lain: insang terbuka, cacat pada mulut (mulut atas pendek dan mulut bawah pendek), dan tulang belakang bengkok di antaranya: 


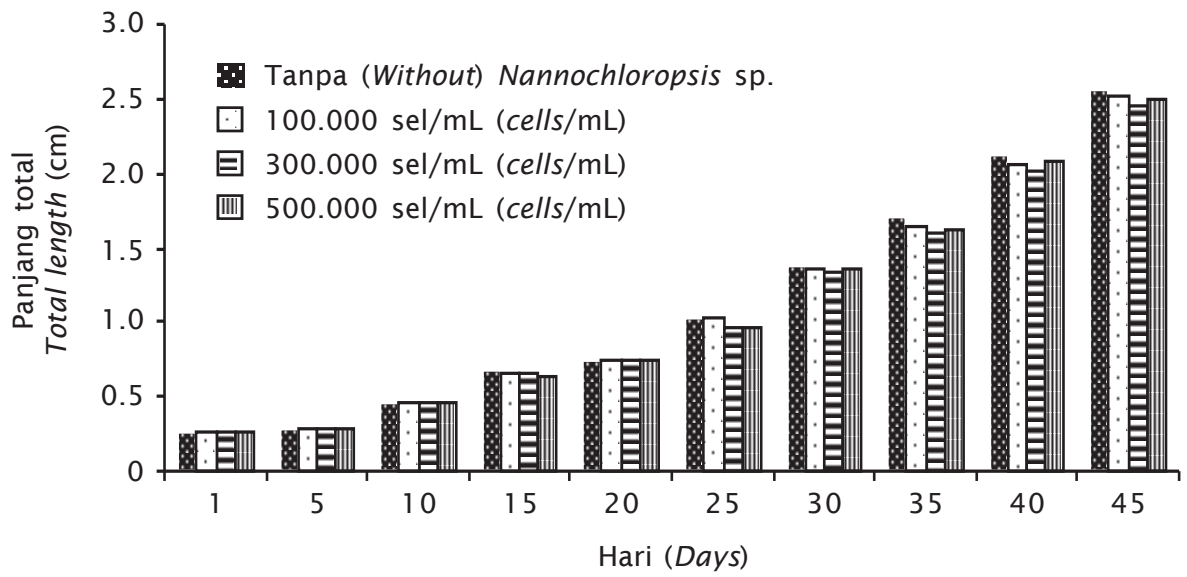

Gambar 1. Panjang total kerapu bebek (Cromileptes altivelis) hingga umur 45 hari pada pemeliharaan dengan penambahan kepadatan Nannochloropsis sp. yang berbeda

Figure 1. Total length of humpback grouper (Cromileptes altivelis) up to 45 days old on reared in various densities of Nannochloropsis sp.

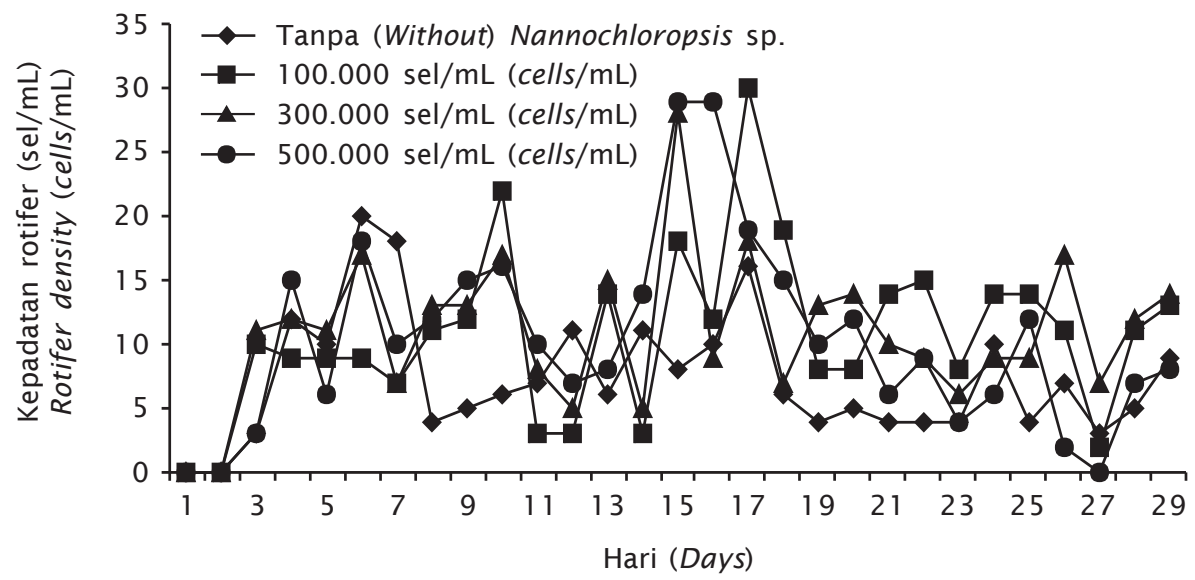

Gambar 2. Kepadatan rotifer pada air pemeliharaan larva kerapu bebek (Cromileptes altivelis) yang dipelihara dengan penambahan kepadatan Nannochloropsis sp. yang berbeda

Figure 2. Rotifer density in humpback grouper (Cromileptes altivelis) larval rearing with various densities of Nannochloropsis sp.

lordosis (tubuh melengkung ke atas), kiposis (tubuh melengkung ke bawah, skiolosis (tubuh terlihat memendek yang disebabkan tulang belakang melengkung ke atas dan ke bawah).

Terdapat beberapa faktor yang menyebabkan terjadinya cacat antara lain: genetik (Paperna, 1978; Piron, 1978), nutrisi (Kanazawa, 1985) termasuk kekurangan vitamin C, D atau phospholipids, trypthophan dapat menyebabkan pertumbuhan tulang tidak normal (Weis \& Weis, 1989; Akiyama et al., 1989), lingkungan seperti penanganan dan kepadatan telur, suhu, oksigen, intensitas cahaya, dan polutan pada air (Haya, 1989; Wiegand et al., 1989; Caris \& Rice, 1990), suhu (Boglione et al., 2001), salinitas (Lee \& Menu, 1981), penyakit (Treasure, 1992) termasuk cara dan kondisi pemeliharaan (Barahona- 

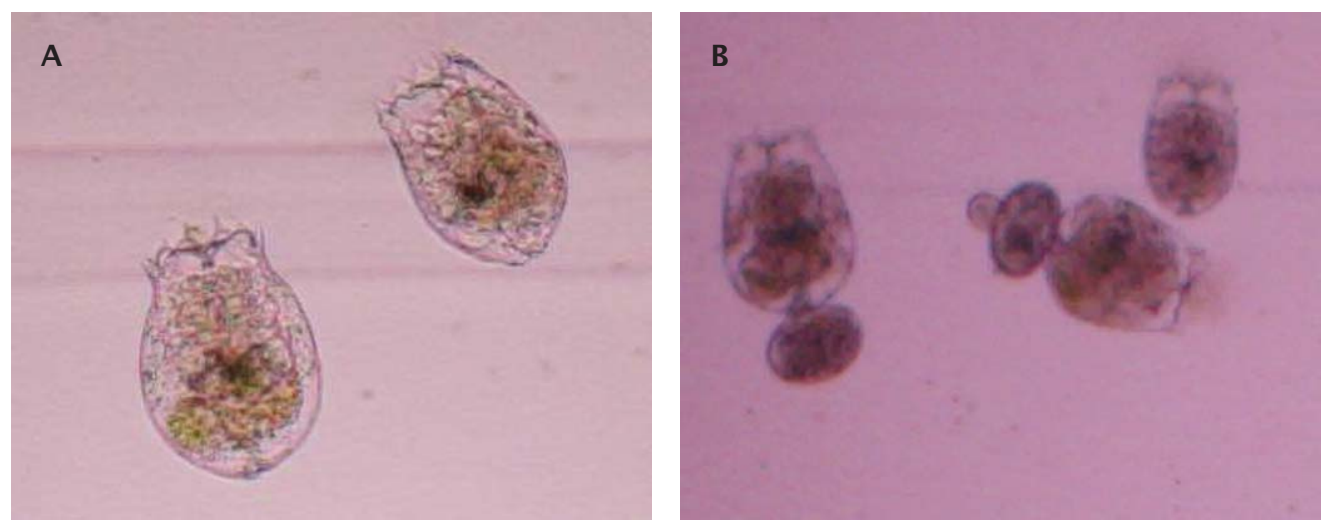

Gambar 3. Kondisi rotifer pada pemeliharaan larva kerapu bebek (Cromileptes altivelis). Tanpa penambahan Nannochloropsis sp. tampak pucat (bening) (A) dan dengan penambahan Nannochloropsis sp. tampak lebih gelap (kehitaman) (B)

Figure 3. Rotifer condition in larval rearing humpback grouper (Cromileptes altivelis). Without Nannochloropsis sp. (clear) (A) and with Nannochloropsis sp. (dark) (B)

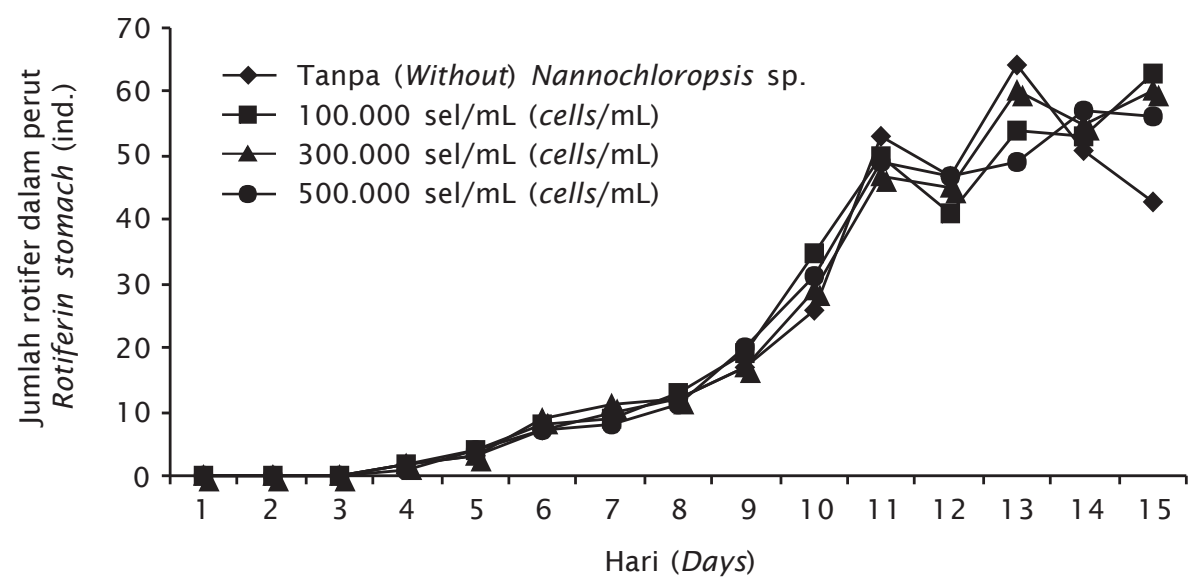

Gambar 4. Jumlah rotifer dalam perut larva kerapu bebek (Cromileptes altivelis) yang dipelihara dengan penambahan kepadatan Nannochloropsis sp. yang berbeda

Figure 4. Rotifer density in humpback grouper (Cromileptes altivelis) stomach larvae reared with various densities of Nannochloropsis $s p$.

Fernandes, 1982; Taniguchi et al., 1984; Divanach et al., 1997; Koumoundouros et al., 2001). Beberapa peneliti mengatakan bahwa tidak berkembangnya gelembung renang adalah termasuk salah satu sebab terjadinya cacat pada ikan (Kitajima et al., 1981; Daoulas et al., 1991).

Parameter kualitas air selama percobaan dapat dilihat pada Tabel 4. Selama pemeliharaan larva dengan kondisi air tersebut tidak mengalami gangguan klinis, karena itu kualitas air tersebut masih dalam taraf layak untuk pemeliharaan larva kerapu bebek.

Nannochloropsis sp. yang digunakan adalah dalam bentuk konsentrat karena itu tidak mempengaruhi kualitas air, seperti terlihat pada Tabel 4 kualitas air pada masingmasing perlakuan hampir sama.

Analisis ekonomi dari operasional pemeliharaan larva kerapu bebek dengan 
Tabel 4. Kisaran kualitas air selama pemeliharaan larva

Table 4. Range of water quality during larval rearing

\begin{tabular}{lcccc}
\hline \multirow{2}{*}{$\begin{array}{c}\text { Parameter } \\
\text { Parameters }\end{array}$} & A & B & C & D \\
\cline { 2 - 5 } & $29.80-30.60$ & $28.90-29.40$ & $28.60-29.70$ & $28.65-29.76$ \\
\hline Suhu (Temperature) $\left({ }^{\circ} \mathrm{C}\right)$ & $8.12-8.17$ & $8.14-8.19$ & $8.15-8.18$ & $8.15-8.19$ \\
$\mathrm{pH}$ & $33.00-35.00$ & $33.00-35.00$ & $33.00-35.00$ & $33.00-35.00$ \\
$\mathrm{Salinitas}($ Salinity) $(\mathrm{ppt})$ & $4.70-6.40$ & $4.30-5.30$ & $4.80-6.50$ & $4.70-5.80$ \\
$\mathrm{DO}(\mathrm{mg} / \mathrm{L})$ & $0.13-0.17$ & $0.11-0.23$ & $0.18-0.20$ & $0.14-0.18$ \\
$\mathrm{NH}_{3}(\mathrm{mg} / \mathrm{L})$ & $0.36-0.96$ & $0.42-0.87$ & $0.35-0.96$ & $0.41-0.93$ \\
$\mathrm{NO}_{2}(\mathrm{mg} / \mathrm{L})$ & $0.13-0.27$ & $0.16-0.29$ & $0.13-0.35$ & $0.14-0.31$ \\
$\mathrm{NO}_{3}(\mathrm{mg} / \mathrm{L})$ & $0.23-0.29$ & $0.13-0.28$ & $0.18-0.23$ & $0.25-0.34$ \\
$\mathrm{PO}_{4}(\mathrm{mg} / \mathrm{L})$ & & &
\end{tabular}

Tabel 5. Tabel rekapitulasi dari analisis usaha (Lampiran 1-4)

Tabel 5. Recapitulation of analysis of business (Appendix 1-4)

\begin{tabular}{lccc}
\hline \multicolumn{1}{c}{$\begin{array}{c}\text { Perlakuan } \\
\text { Treatments }\end{array}$} & $\begin{array}{c}\text { Biaya produksi } \\
\text { Cost production } \\
\text { (Rp) }\end{array}$ & $\begin{array}{c}\text { Hasil kotor } \\
\text { Gross profit } \\
\text { (Rp) }\end{array}$ & $\begin{array}{c}\text { Laba } \\
\text { Net profit } \\
\text { (Rp) }\end{array}$ \\
\hline Tanpa Nannochlopsis sp. & $4,120,000$ & $2,951,000$ & $2,361,000$ \\
Without Nannochloropsis sp. & $8,970,000$ & $15,973,000$ & $12,778,000$ \\
$100.000 \mathrm{sel} / \mathrm{mL}$ (cells/mL) & $11,820,000$ & $19,109,000$ & $15,287,000$ \\
$300.000 \mathrm{sel} / \mathrm{mL}$ (cells/mL) & $16,870,000$ & $30,055,000$ & $24,044,000$ \\
\hline $500.000 \mathrm{sel} / \mathrm{mL}$ (cells/mL) & & & \\
\hline
\end{tabular}

Keterangan (Note):

Harga benih kerapu bebek ukuran $3 \mathrm{~cm}$ : Rp. 3.600,-/ekor

Humpback grouper seed price: Rp. 3,600,-/pcs (size of $3 \mathrm{~cm}$ )

penambahan kepadatan Nannochloropsis sp. yang berbeda dapat dilihat pada Lampiran 1, 2, 3, dan 4. Sedangkan rekapitulasi analisis usaha dapat dilihat pada Tabel 5. Dari hasil perhitungan, perlakuan dengan penambahan kepadatan Nannochloropsis sp. $500.000 \mathrm{sel} /$ $\mathrm{mL}$ mempunyai hasil bersih lebih tinggi dibandingkan dengan perlakuan yang lain.

\section{KESIMPULAN}

Larva kerapu bebek yang dipelihara dengan penambahan Nannochloropsis sp., kepadatan $500.000 \mathrm{sel} / \mathrm{mL}$ mempunyai sintasan yang lebih tinggi dan dari hasil analisis ekonomi menghasilkan keuntungan lebih besar dibandingkan dengan perlakuan yang lain.
Pertumbuhan panjang tidak menunjukkan perbedaan, abnormalitas masih terjadi pada semua perlakuan baik kontrol maupun dengan penambahan Nannochloropsis sp.

\section{DAFTAR ACUAN}

Anonim. 2008. Pedoman umum cara pembenihan ikan yang baik (CPIB). Departemen Kelautan dan Perikanan, Direktorat Jenderal Perikanan Budidaya, Direktorat Pembenihan, $61 \mathrm{hlm}$.

Akiyama, T., Murai, T., \& Mori, K. 1989. Role of tryptophan metabolites in inhibition of spinal deformity of Chum Salmon fry caused by tryptophan deficiency. Bull. Jpn. Soc. Sci. Fish., 52: 1,249-1,254. 
Barahona-Fernandes, M.H. 1982. Body deformation in hatchery reared European sea bass Dicentrarchus labrax (L). Types, prevalence and effect on fish survival. $J$. Fish Biol., 21 : 239-249.

Boglione, C., Gagliardi, F., Scardi, F., \& Cataudella, S. 2001. Skeletal descriptors and quality assessment in larvae and postlarva of wild-caught and hatchery-reared gilthead sea bream (Sparus aurata L.). Aquaculture, 192: 1-22.

Caris, M.G. \& Rice, S.D. 1990. Abnormal development and growth reductions of Pollock Theragra chalcogramma embryos exposed to water-soluble fractions of oil. Fish. Bull. US, 88: 29-37.

Chou \& Lee. 1998. Commercial marine fish farming in Singapore. Aquaculture Research, 10: 767-777.

Daoulas, Ch., Economou, A.N., \& Bantavas, I. 1991. Osteological abnormalities in laboratory reared sea bass (Dicentrarchus labrax) fingerlings. Aquaculture, 97: 169180.

Divanach, P., Papandroukalis, N., Anastasiadis, P., Koumoundouros, G., \& Kentouri, M., 1997. Effect of water currents on the development of skeletal deformities in sea bass(Dicentrarchus labrax L.) with fuctional swimbladder during postlarval and nursey phase. Aquaculture, 156L: 145155.

Eri, S., Seiichi, T., \& Kosaku Y. 2003. Effect of water color and light intensity on water surface tension-related deaths in larval stage of the red-spotted grouper, Ephinephelus akaara. Suisanzoshoku, 51(1): 81-85.

Haya, K. 1989. Toxicity of pyrethroid insecticides to fish. Environ. Oxicol. Chem., 8: 381391.

Ismi, S., Wardoyo, Setyawati, K.M., \& Trijoko. 2004. Pengaruh frekuensi pemberian minyak ikan pada pemeliharaan larva kerapu bebek (Cromileptes altivelis). J. Pen. Perik. Indonesia, 10(5): 61-65.

Ismi, S. 2005. Pemeliharaan larva kerapu. Bahan Kuliah pada Desiminasi Budidaya Laut Berkelanjutan Balai Besar Riset Perikanan Budidaya Laut Gondol bekerja sama dengan Japan International Cooperation Agency dan Dirjen Perikanan Budidaya, Departemen Kelautan dan Perikanan, $8 \mathrm{hlm}$.

Ismi, S., Wardoyo, Tridjoko, \& Setiadi, E. 2007. Pengaruh penggunaan skimmer terhadap abnormalitas pada pemeliharaan larva kerapu bebek (Cromileptes altivelis). J. Ris. Akuakultur, 2(1): 19-23.

Kanazawa, A. 1985. Essential fatty acid and lipid requirement of fish. Nutrition and Feeding in Fish. Academic Press, London, p. 281 298.

Kawahara, S. \& Ismi, S. 2003. Statistik produksi benih ikan kerapu Indonesia 1999-2002. Balai Besar Riset Perikanan Budidaya Laut Gondol bekerja sama dengan Balai Budidaya Laut Lampung dan Balai Budidaya Air Payau Situbondo. Departemen Kelautan dan Perikanan, $16 \mathrm{hlm}$.

Kitajima, C., Tsukashima, Y., Fujita, S., Watanabe, T., \& Yone, Y. 1981. Relationship between uninflated swimbladders and lordotic deformity in hatchery reared sea brem Pagrus major. Bull. Jpn. Soc. Sci. Fish., 47: 1,289-1,294.

Koumoundouros, G., Divanach, P., \& Kentouri, M. 2001. The effect of rearing conditions on development of saddleback syndrome and caudal fin deformities in Dentex dentex (L). Aquaculture, 200: 285-304.

Koven, M.W., Tandler, A., Kissil, G.W., Sklan, D., Frieslander, O., \& Harel, M. 1990. The effect of dietary n-3 polyunsaturated fatty acid on growth, survival and swim bladder development in Sparus aureta larvae. Aquaculture, 91: 131-141.

Lee, C.S. \& Menu, B. 1981. Effect of salinity on egg development and hatching in grey mullet Mugil cephalus L. J. Fish Biol., 19: 179-188.

Okauchi, M. 2004. An assessment of the beneficial roles of Nannochloropsis oculata in larval rearing of marine finfish. Bull. Fish. Agen Supplement, 1: 83-90.

Otsrowski, A.C. \& Divakaran, S. 1990. Survival and bioconversion of $\mathrm{n}-3$ fatty acid during early development of dolphin (Corypaena hyppuras) larvae fed oil enriched rotifer. Aquaculture, 89: 273-285.

Paperna, I. 1978. Swimbladder and skeletal deformations in hatchery dred Sparus aurata. J. Fish Biol., 12: 109-1 14.

Piron, R.D., 1978. Spontaneous skeletal deformities in Zebra Danio (Brachydanio rerio) bear for fish toxicity tests. J. Fish Biol., 13: 79-83.

Radhakrishnan, E.V., Rekha, D.C., Tangaraja, R., \& Unnikrshnan, C. 2009 . Effect of Nannochloropsis salina on the survival and growth of phyllosoma of the tropical 
spiny lobster, Panulirus homarus L. under laboratory condition. J. Mar. Biol. Ass. India, 51(1): 52-60.

Sorgeloss, P., Leger, P., \& Laveus, P. 1998. Improved larval rearing of European, Asian sea bass, sea bream, mahi-mahi, siganid and milkfish using enriched diets for rotifer and Artemia. World Aquaculture, 19: 7879.

Sugama, K., Tridjoko, Slamet, B., Ismi, S., Setiadi, E., \& Kawahara, S. 2001. Petunjuk teknis produksi benih ikan kerapu bebek, Cromileptes altivelis. Balai Besar Riset Perikanan Budidaya Laut Gondol, Pusat Riset dan Pengembangan Eksploitasi Laut dan Perikanan, Departemen Kelautan dan Perikanan dan Japan International Cooperation Agency, $40 \mathrm{hlm}$.

Sutarmat, T., Hanafi, A., \& Kawahara, S. 2002. Leaflet budidaya kerapu bebek (Cromileptes altivelis) di keramba jaring apung. Balai Besar Riset Perikanan Budidaya Laut Gondol bekerja sama dengan Japan International Cooperation Agency, $2 \mathrm{hlm}$.

Sutarmat, T, Ismi, S., Hanafi, A., \& Kawahara, S. 2003. Petunjuk teknis budidaya kerapu bebek (Cromileptes altivelis) di karamba jaring apung. Balai Besar Riset Perikanan Budidaya Laut Gondol, Pusat Riset Perikanan Budidaya, Badan Riset Kelautan dan Perikanan, Departemen Kelautan dan Perikanan dan Japan International Cooperation Agency, $56 \mathrm{hlm}$.

Takaaki, K., Takashi, S., \& Sato, N. 2002. Effects of supplement of Nannochloropsis oculata to rearing water on initial feeding and survival in larval barfin flounder Verasper moseri. Scientific Reports of Hokkaido Fisheries Experimental Station, 63: 55-63.

Taniguchi, N., Azumi, K., \& Umeda, S. 1984. Difference due to parents in incidence of vertebral malformation in artificially-bred sea bream. Bull. Jpn. Soc. Sci. Fish., 50(5): 787-792.

Treasure, J. 1992. Vertebral anomalies associated with Myxobolus sp. in perch, Perca fluvialitis L., in a Scoottish loch. Bull. Eur. Assoc. Fish Pathol., 12(2): 63-66.

Webster, C.D. \& Lovell, R.T. 1990. Response of stripped bass larvae fed brine shrimp from different sources containing different fatty acid composition. Aquaculture, 90: 49-61.

Weis, J.S. \& Weis, P. 1989. Effects of environmental pollutans on early fish development. Aqua. Sci., 1: 45-73.

Wiegand, M.D., Hataley, J.M., Kitchen, C.L., \& Buchanan, L.G. 1989. Induction of developmental abnormalities in larval goldfish, Carassius auratus L., under cool incubation conditions. J. Fish Biol., 35: 85-95. 
Lampiran 1. Perhitungan biaya operasional pemeliharaan larva kerapu bebek (Cromileptes altivelis) tanpa penambahan Nannochloropsis sp. dalam air pemeliharaan

Appendix 1. Operational cost of humpback grouper (Cromileptes altivelis) larval rearing without Nannochloropsis sp.

\begin{tabular}{|c|c|c|}
\hline $\begin{array}{l}\text { Fakt or produksi } \\
\text { Production variable }\end{array}$ & $\begin{array}{l}\text { Harga satuan } \\
\text { Unit price } \\
(x \operatorname{Rp~} 1,000,-)\end{array}$ & $\begin{array}{l}\text { Jumlah harga } \\
\text { Total price } \\
\text { (x Rp } 1,000,-)\end{array}$ \\
\hline $\begin{array}{l}\text { Telur kerapu bebek (butir) } \\
\text { Humpback grouper eggs (pcs) } 100.000 @ \text { Rp 6.0,- }\end{array}$ & 6.0 & 600 \\
\hline Pakan buatan (Artificial feed) & & 1,000 \\
\hline $\begin{array}{l}\text { Artemia (1 kaleng) } \\
\text { Artemia (1 can) }\end{array}$ & 300 & 300 \\
\hline $\begin{array}{l}\text { Bahan pengkaya }(0,5 \mathrm{~kg}) \\
\text { Enrichment agent }(0.5 \mathrm{~kg})\end{array}$ & 900 & 450 \\
\hline $\begin{array}{l}\text { Vitamin } C(0,5 \mathrm{~kg}) \\
\text { Vitamin } C(0.5 \mathrm{~kg})\end{array}$ & 300 & 150 \\
\hline $\begin{array}{l}\text { Minyak ikan }(0,5 \text { pak }) \\
\text { Fish oil }(0.5 \text { pack })\end{array}$ & 40 & 20 \\
\hline Listrik selama 3 bulan (Electricity for 3 months) & 200 & 600 \\
\hline $\begin{array}{l}\text { Pupuk untuk kultur plankton } \\
\text { Fertilizer for plankton culture }\end{array}$ & & 1,000 \\
\hline Caporite, Chlorine, Thiosulfate & & 200 \\
\hline Lain-lain (Others) & & 500 \\
\hline Jumlah (Total) & & 4,120 \\
\hline $\begin{array}{l}\text { Panen ukuran } 3 \mathrm{~cm} \text { (Harvest size of } 3 \mathrm{~cm}) \\
\text { Survival rate: } 3.5 \% \times 60,000 \text { ekor }(p c s)=2,100 \text { ekor } \\
(p c s)-\text { cacat }(\text { deformity) } 75 \text { ekor }(p c s)=(2,025 \times \mathrm{Rp} \\
3,600,-)-3 \% \text { (discount) }\end{array}$ & & 7,071 \\
\hline Hasil kotor (Gross profit) & & 2,951 \\
\hline Teknisi (Technician): 20\% x Rp 45,926,000,- & & 590 \\
\hline Hasil bersih (Nett profit) & & 2,361 \\
\hline
\end{tabular}

Keterangan (Note):

Biaya operasional 1 ekor yuwana ukuran $3 \mathrm{~cm}$ : Rp 2.325,-

Operational cost: $R p$ 2,325,-/pcs (size of $3 \mathrm{~cm}$ juvenile) 
Lampiran 2. Perhitungan biaya operasional pemeliharaan larva kerapu bebek (Cromileptes altivelis) dengan penambahan Nannochloropsis sp. kepadatan $100.000 \mathrm{sel} / \mathrm{mL}$ dalam air pemeliharaan

Appendix 2. Operational cost of humpback grouper (Cromileptes altivelis) larva rearing with addition of Nannochloropsis sp. 100,000 cells/mL into rearing water

\begin{tabular}{|c|c|c|}
\hline $\begin{array}{l}\text { Fakt or produksi } \\
\text { Production variable }\end{array}$ & $\begin{array}{c}\text { Harga sat uan } \\
\text { Unit price } \\
\text { (x Rp } 1,000,-)\end{array}$ & $\begin{array}{l}\text { Jumlah harga } \\
\text { Total price } \\
\text { (x Rp 1,000,-) }\end{array}$ \\
\hline $\begin{array}{l}\text { Telur kerapu bebek (butir) } \\
\text { Humpback grouper eggs (pcs) 100.000 @ Rp 6.0,- }\end{array}$ & 6.0 & 600 \\
\hline Pakan buatan (Artificial feed) & & 2,500 \\
\hline $\begin{array}{l}\text { Artemia (4 kaleng) } \\
\text { Artemia (4 can) }\end{array}$ & 300 & 1,200 \\
\hline $\begin{array}{l}\text { Bahan pengkaya }(1 \mathrm{~kg}) \\
\text { Enrichment agent }(1 \mathrm{~kg})\end{array}$ & 900 & 900 \\
\hline $\begin{array}{l}\text { Vitamin C (1 kg) } \\
\text { Vitamin C }(1 \mathrm{~kg})\end{array}$ & 300 & 300 \\
\hline $\begin{array}{l}\text { Minyak ikan }(0,5 \text { pak }) \\
\text { Fish oil }(0.5 \text { pack })\end{array}$ & 40 & 20 \\
\hline Listrik selama 3 bulan (Electricity for 3 months) & 200 & 600 \\
\hline $\begin{array}{l}\text { Pupuk untuk kultur plankton } \\
\text { Fertilizer for plankton culture }\end{array}$ & & 1,000 \\
\hline $\begin{array}{l}\text { Konsentrasi Nannochloropsis sp. }(1 \mathrm{~L}) \\
\text { Nannochloropsis sp. concentrate }(1 \mathrm{~L})\end{array}$ & 850 & 850 \\
\hline Caporite, Chlorine, Thiosulfate & & 200 \\
\hline Lain-lain (Others) & & 800 \\
\hline Jumlah (Total) & & 8,970 \\
\hline
\end{tabular}

Panen ukuran $3 \mathrm{~cm}$ (Harvest size of $3 \mathrm{~cm}$ )

Survival rate: $14.2 \% \times 60,000$ ekor $(p c s)=8,520$ ekor

(pcs) - cac at (deformity) 1,377 ekor (pcs) $=(7,143 \times \mathrm{Rp}$ $3,600,-)$ - 3\% (discount)

\begin{tabular}{cc}
\hline Hasil kotor (Gross profit) & 15,973 \\
\hline Teknisi (Technician): $20 \% \times \mathrm{Rp} 45,926,000,-$ & 3,195 \\
\hline Hasil bersih (Net profit) & 12,778 \\
\hline
\end{tabular}

Keterangan (Note):

Biaya operasional 1 ekor yuwana ukuran $3 \mathrm{~cm}$ : Rp 1.700,-

Operational cost: $R p$ 1,700,-/pcs (size of $3 \mathrm{~cm}$ juvenile) 
Lampiran 3. Perhitungan biaya operasional pemeliharaan larva kerapu bebek (Cromileptes altivelis) dengan penambahan Nannochloropsis sp. kepadatan $300.000 \mathrm{sel} / \mathrm{mL}$ dalam air pemeliharaan

Appendix 3. Operational cost of humpback grouper (Cromileptes altivelis) larval rearing with addition of Nannochloropsis sp. 300,000 cells/mL into rearing water

\begin{tabular}{|c|c|c|}
\hline $\begin{array}{l}\text { Fakt or produksi } \\
\text { Production variable }\end{array}$ & $\begin{array}{l}\text { Harga satuan } \\
\text { Unit price } \\
\text { (x Rp } 1,000,-)\end{array}$ & $\begin{array}{l}\text { Jumlah harga } \\
\text { Total price } \\
\text { (x Rp } 1,000,-)\end{array}$ \\
\hline $\begin{array}{l}\text { Telur kerapu be bek (butir) } \\
\text { Humpback grouper eggs (pcs) } 100.000 @ \text { Rp 6.0,- }\end{array}$ & 6.0 & 600 \\
\hline Pakan buatan (Artificial feed) & & 3,500 \\
\hline $\begin{array}{l}\text { Artemia (5 kaleng) } \\
\text { Artemia (5 can) }\end{array}$ & 300 & 1,500 \\
\hline $\begin{array}{l}\text { Bahan pengkaya }(1 \mathrm{~kg}) \\
\text { Enrichment agent }(1 \mathrm{~kg})\end{array}$ & 900 & 900 \\
\hline $\begin{array}{l}\text { Vitamin C (1 kg) } \\
\text { Vitamin C }(1 \mathrm{~kg})\end{array}$ & 300 & 300 \\
\hline $\begin{array}{l}\text { Minyak ikan }(0,5 \text { pak }) \\
\text { Fish oil }(0.5 \text { pack })\end{array}$ & 40 & 20 \\
\hline Listrik selama 3 bulan (Electricity for 3 months) & 200 & 600 \\
\hline $\begin{array}{l}\text { Pupuk untuk kultur plankton } \\
\text { Fertilizer for plankton culture }\end{array}$ & & 1,500 \\
\hline $\begin{array}{l}\text { Konsentrasi Nannochloropsis sp. }(2 \mathrm{~L}) \\
\text { Nannochloropsis sp. concentrate }(2 \mathrm{~L})\end{array}$ & 850 & 1,700 \\
\hline Caporite, Chlorine, Thiosulfate & & 200 \\
\hline Lain-lain (Others) & & 1,000 \\
\hline Jumlah (Total) & & 11,820 \\
\hline $\begin{array}{l}\text { Panen ukuran } 3 \mathrm{~cm} \text { (Harvest size of } 3 \mathrm{~cm}) \\
\text { Survival rate: } 19.5 \% \times 60,000 \text { ekor }(p c s)=11,700 \text { ekor } \\
(p c s)-\text { cacat (deformity) } 2,843 \text { ekor }(p c s)=(8,857 \times \mathrm{Rp} \\
3,600,-)-3 \% \text { (discount) }\end{array}$ & & 30,929 \\
\hline Hasil kotor (Gross profit) & & 19,109 \\
\hline Teknisi (Technician): 20\% x Rp 45,926,000,- & & 3,822 \\
\hline Hasil bersih (Nett profit) & & 15,287 \\
\hline
\end{tabular}

Keterangan (Note):

Biaya operasional 1 ekor yuwana ukuran $3 \mathrm{~cm}$ : Rp 1.770,-

Operational cost: $R p$ 1,770,-/pcs (size of $3 \mathrm{~cm}$ juvenile) 
Lampiran 4. Perhitungan biaya operasional pemeliharaan larva kerapu bebek (Cromileptes altivelis) dengan penambahan Nannochloropsis sp. kepadatan $500.000 \mathrm{sel} / \mathrm{mL}$ dalam air pemeliharaan

Appendix 4. Operational cost of humpback grouper (Cromileptes altivelis) larval rearing with addition of Nannochloropsis sp. 500,000 cells $/ \mathrm{mL}$ into rearing water

\begin{tabular}{|c|c|c|}
\hline $\begin{array}{l}\text { Fakt or produksi } \\
\text { Production variable }\end{array}$ & $\begin{array}{c}\text { Harga sat uan } \\
\text { Unit price } \\
\text { (x Rp } 1,000,-)\end{array}$ & $\begin{array}{l}\text { Jumlah harga } \\
\text { Total price } \\
\text { (x Rp 1,000,-) }\end{array}$ \\
\hline $\begin{array}{l}\text { Telur ke rapu bebek (butir) } \\
\text { Humpback grouper eggs (pcs) } 100.000 @ \text { Rp 6.0,- }\end{array}$ & 6.0 & 600 \\
\hline Pakan buatan (Artificial feed) & & 4,600 \\
\hline $\begin{array}{l}\text { Artemia (7 kaleng) } \\
\text { Artemia ( } 7 \text { can) }\end{array}$ & 300 & 2,100 \\
\hline $\begin{array}{l}\text { Bahan pengkaya }(1 \mathrm{~kg}) \\
\text { Enrichment agent }(1 \mathrm{~kg})\end{array}$ & 900 & 900 \\
\hline $\begin{array}{l}\text { Vitamin C (1 kg) } \\
\text { Vitamin C }(1 \mathrm{~kg})\end{array}$ & 300 & 300 \\
\hline $\begin{array}{l}\text { Minyak ikan }(0,5 \text { pak }) \\
\text { Fish oil }(0.5 \text { pack })\end{array}$ & 40 & 20 \\
\hline Listrik selama 3 bulan (Electricity for 3 months) & 200 & 600 \\
\hline $\begin{array}{l}\text { Pupuk untuk kultur plankton } \\
\text { Fertilizer for plankton culture }\end{array}$ & & 3,500 \\
\hline $\begin{array}{l}\text { Konsentrasi Nannochloropsis sp. }(3 \mathrm{~L}) \\
\text { Nannochloropsis sp. concentrate }(3 \mathrm{~L})\end{array}$ & 850 & 2,550 \\
\hline Caporite, Chlorine, Thiosulfate & & 200 \\
\hline Lain-lain (Others) & & 1,500 \\
\hline Jumlah (Total) & & 16,870 \\
\hline
\end{tabular}

Panen ukuran $3 \mathrm{~cm}$ (Harvest size of $3 \mathrm{~cm}$ )

Survival rate: $26.8 \% \times 60,000$ ekor $(p c s)=16,080$ ekor

$(p c s)$ - cac at (deformity) 2,642 ekor (pcs) $=(13,438 \times$

Rp 3,600,-) - 3\% (discount)

\begin{tabular}{cc}
\hline Hasil kotor (Gross profit) & 30,055 \\
\hline Teknisi (Technician): $20 \% \times$ Rp 45,926,000,- & 6,011 \\
\hline Hasil bersih (Nett profit) & 24,044 \\
\hline
\end{tabular}

Keterangan (Note):

Biaya operasional 1 ekor yuwana ukuran $3 \mathrm{~cm}$ : Rp 1.700,-

Operational cost: $R p$ 1,700,-/pcs (size of $3 \mathrm{~cm}$ juvenile) 